\title{
PENDIDIKAN KARAKTER DALAM BUKU BANJAR NEGERI HARUM 1001 GURINDAM KARYA HAJI IBERAMSYAH BARBARY
}

\author{
Litha Luthfiyanti ${ }^{1}$, Lili Agustina ${ }^{2}$, dan Isna Kasmilawati ${ }^{3}$ \\ UNIVERSITAS LAMBUNG MANGKURAT ${ }^{1}$ \\ Jalan Brigjend H. Hasan Baseri Kecamatan Banjarmasin Utara \\ Kalimantan Selatan. Kode pos 70123, \\ email: litaluthfiya@gmail.com \\ STKIP PGRI Banjarmasin ${ }^{2,3}$ \\ Jalan Sultan Adam, Komplek H. Iyus, No. 18 RT.23 Banjarmasin \\ Kalimantan Selatan. Kode pos 70121, \\ email:
}

\section{ABSTRAK}

Sebuah karya sastra yang baik adalah karya sastra yang dapat mempengaruhi pembaca sehingga menjadi manusia yang lebih baik. Begitu pula dengan buku Banjar Negeri Harum 1001 Gurindam karya Haji Iberamsyah Barbary yang penuh dengan pesan kebaikan. Berdasarkan rumusan masalah, tujuan penelitian ini untuk. Mengetahui dan mendeskripsikan pendidikan karakter yang terdapat dalam buku Banjar Negeri Harum 1001 Gurindam Karya Haji Iberamsyah Barbary.

Pendekatan yang digunakan dalam penelitian ini adalah pendekatan kualitatif. Metode yang digunakan adalah metode deskriptif. Sumber data yang digunakan dalam penelitian ini adalah dokumen. Dokumen yang digunakan adalah buku Banjar Negeri Harum 1001 gurindam karya Haji Iberamsyah Barbary. Data dari penelitian ini adalah isi dari gurindam yang terdiri dari 1001 ayat. Teknik pengumpulan data menggunakan dokumen dengan literatur sebagai dokumen dalam penelitian ini. Teknik analisis yang digunakan dalam penelitian ini adalah teknik analisis mengalir.

Pada penelitian ini dapat disimpulkan bahwa pendidikan karakter dalam buku Banjar Negeri Harum 1001 Gurindam Karya Haji Iberamsyah Barbary terdapat 18 karakter, yaitu: 1) religius, 2) jujur, 3) toleransi, 4) disiplin, 5) kerja keras, 6) kreatif, 7) mandiri, 8) demokratis, 9) rasa ingin tahu, 10) semangat kebangsaan atau nasionalisme, 11) cinta tanah air, 12) menghargai prestasi, 13) komunikatif, 14) cinta damai, 15) gemar membaca, 16) peduli lingkungan, 17) peduli sosial, 18) tanggung jawab.

Kata kunci: pendidikan karakter, gurindam

\section{PENDAHULUAN}

Sastra merupakan salah satu karya seni bermediakan bahasa. Sastra telah menempati dimensi ruang dan waktu dalam peradaban manusia. Karya sastra terbagi menjadi dua, yaitu karya sastra lama dan karya sastra baru. Salah satu contoh sastra lama adalah gurindam. Gurindam merupakan 
karya sastra lama yang berbentuk puisi yang terdiri dari dua baris kalimat yang memiliki rima atau sajak yang sama. Gurindam sendiri memiliki lebih dari satu bait yang terdiri dari 2 baris tiap baitnya. Baris pertama pada gurindam merupakan baris syarat, masalah, persoalan atau perjanjian dan baris kedua merupakan jawaban atau akibat dari masalah atau hal yang terjadi pada baris pertama.

Gurindam yang sangat terkenal di Indonesia adalah gurindam dua belas karya Raja Ali Haji yang berasal dari Riau. Gurindam ini ditulis pada abad ke 19. Namun, di era modern sekarang ini, salah satu sastrawan dari Kalimantan Selatan yang bernama Iberamsyah Barbary telah menciptakan sebuah karya yang begitu fenomenal, yaitu buku yang berjudul Banjar Negeri Harum 1001 Gurindam. Gurindam yang terdiri dari 1001 ayat dan 143 pasal ini berisikan segala kesan, pesan, peringatan, nasihat, dan tutur peristiwa orang-orang terdahulu yang menegakkan rasa kebangsaan. Gurindam yang penuh nilai-nilai kebajikan ini menginspirasi pembaca untuk senantiasa berbuat baik dan secara tidak langsung membentuk karakter baik orang yang membacanya.

Sebuah karya sastra tidak hanya berfungsi sebagai hiburan, tetapi dapat dijadikan sebagai alat untuk membangun karakter. Sebuah karya sastra yang baik adalah karya sastra yang dapat mempengaruhi pembaca sehingga menjadi manusia yang lebih baik. Begitu pula dengan buku Banjar Negeri Harum 1001 Gurindam karya Haji Iberamsyah Barbary yang penuh dengan pesan kebaikan. Hal inilah yang menjadi alasan peneliti untuk meneliti buku Banjar Negeri Harum 1001 Gurindam.

\section{METODE}

Pendekatan yang digunakan dalam penelitian ini adalah pendekatan kualitatif Penelitian ini adalah jenis penelitian kualitatif yang menggunakan metodologi kualitatif desktiptif. Bogdan dan Taylor (1992:22) mendefinisikan bahwa metodologi kualitatif sebagai prosedur penelitian yang menghasilkan data deskriptif berupa kata-kata tertulis berupa kata-kata tertulis atau lisan dari orang-orang dan perilaku yang dapat diamati. Dengan demikian, penelitian ini akan mendeskripsikan pendidikan karakter dalam buku Buku Banjar Negeri Harum 1001 gurindam karya Haji Iberamsyah Barbary. 


\section{HASIL DAN PEMBAHASAN}

\section{Pendidikan Karakter dalam Buku Banjar Negeri Harum 1001 Gurindam Karya Haji Iberamsyah Barbary}

Pendidikan karakter adalah sebuah transformasi nilai-nilai kehidupan untuk ditumbuhkembangkan dalam kepribadian seseorang sehingga menjadi satu dalam perilaku kehidupan seseorang. Gunawan (2011:30) menyatakan pendidikan karakter berfungsi untuk mengembangkan potensi dasar agar berhati, berpikiran, dan berperilaku baik; memperkuat dan membangun perilaku bangsa yang multikultur; dan meningkatkan peradaban bangsa yang kompetitif dalam pergaulan manusia.

Kementerian Pendidikan Nasional telah merumuskan 18 nilai karakter yang akan ditamamkan dalam diri peserta didik sebagai upaya membangun karakter bangsa, yaitu religius, jujur, toleransi, disiplin, kerja keras, kreatif, mandiri, demokratis, rasa ingin tahu, semangat kebangsaan atau nasionalisme, cinta tanah air, menghargai prestasi, komunikatif, cinta damai, gemar membaca, peduli lingkungan, peduli sosial, dan tanggung jawab.

1. Religius

Religius, yakni ketaatan dan kepatuahan dalam memahami dan melaksanakan ajaran agama (aliran kepercayaan) yang dianut, termasuk dalam hal ini adalah sikap toleran terhadap pelaksanaan ibadah agama (aliran kepercayaan) lain, serta hidup rukun dan berdampingan. Nilai Pendidikan Karakter religius dapat dilihat dalam gurindam berikut ini.

\section{Bismilah}

Barang siapa memulai ikhtiar dengan nama Allah Akanlah hasil usaha beberkah dan bertuah

Barang siapa memulai kata dengan nama Allah Akanlah terhindar dari khilap dan salah

Barang siapa memulai hujah dengan nama Allah Aakanlah dia terpeliharaa dari amanah

Barang siapa mengucapkan sumpah demi Allah Berhati-hatilah menerima Amanah

Beribadahlah karena Allah

Karena kita penerima amanah sebagai Khalifah

Indahnya hidup dengan berserah Agarlah jiwa dan badan diberi marwah 
Nilai pendidikan karakter religius sangat tercermin dalam gurindam yang berjudul bismillah, karena setiap kalimat dalam gurindam tersebut memperlihatkan bagaimana seharusnya manusia taat dan patuh dalam memahami dan melaksanakan ajaran agama. Isi dari gurindam tersebut mengajarkan bahwa jika manusia berikhtiar atas nama Allah maka usahanya akan berkah. Jadi dalam hidup sehari-hari, setiap melakukan pekerjaan apa pun seharusnya berniat untuk ibadah. Artinya melakukan segala sesuatu untuk Allah.

Selain itu, hal yang disampaikan dalam gurindam tersebut adalah setiap manusia harus berhati-hati dalam mengucapkan sumpah atas nama Allah. Karena sumpah adalah amanah yang wajib dilaksanakan oleh orang yang bersumpah. Dan sebagai manusia yang terlahir untuk menjadi khalifah/ pemmpin di muka bumi harus berpegang teguh pada ajaran Allah.

2. Jujur

Jujur adalah perilaku yang didasarkan pada upaya menjadikan diri sebagai seorang yang selalu dapat dipercaya dalam perkataan, tindakan, dan pekerjaan, baik terhadap diri sendiri maupun orang lain. Nilai pendidikan karakter jujur dapat dilihat pada gurindam di bawah ini.

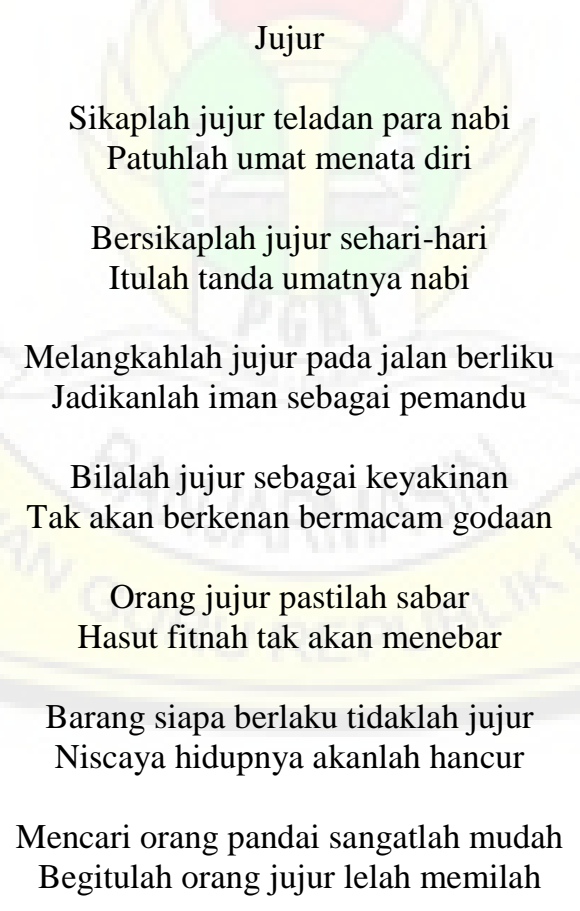

Gurindam yang berjudul "Jujur" di atas mengajarkan bahwa setiap manusia harus bersikap jujur dalam kehidupan sehari-hari. Jujur merupakan teladan para nabi, yang jika dilaksanakan tentu akan sangat bermanfaat bagi kehidupan. Jujur dalam berkata dan berbuat akan membuat hidup manusia lebih tertata, hasut dan fitnah pun tidak akan menyebar. 


\title{
3. Toleransi
}

Toleransi menurut Mustari (2011:205) adalah sikap yang tidak memaksakan pemikiran, keyakinan, dan kebiasaannya sendiri pada orang lain; memahami dan menghargai keyakinan atau kebiasaan orang lain. Nilai pendidikan karakter toleransi dapat dilihat pada gurindam berikut ini.

\author{
Negara Kepulauan \\ Indonesia negara kepulauan \\ Itulah negeriku yang menawan \\ Dari barat ke timur tatah permata \\ Itulah untaian jambrut khatulistiwa \\ Beribu pulau terhampar indah \\ Bagai dewa sedang bermadah \\ Bermacam suku mendiami \\ Itulah putra putri ibu pertiwi \\ Bermacam bahasa bercengkrama \\ Itulah tanda sambung rasa \\ Bermacam suku dan adat istiadat \\ Tandalah rukun saling mengikat \\ Seribu pulau kekuatan nyata \\ Bagi anak bangsa yang membuka mata
}

Nilai pendidikan karakter yang tercermin dalam gurindam di atas adalah toleransi. Dapat dilihat pada kalimat "Bermacam suku dan adat istiadat, Tandalah rukun saling mengikat". Indonesia sebagai negara kepulauan memiliki berbagai macam agama, suku, bahasa, dan budaya. Namun, walaupun berbeda, rakyat Indonesia harus saling menghormati, agar tercipta kerukunan dan kedamaian dalam kehidupan. Kalimat "seribu pulau kekuatan nyata, bagi anak bangsa yang membuka mata" juga menyampaikan pesan bahwa sebagai anak bangsa yang tinggal di negara kepulauan yang kaya akan suku bangsa harus bangga akan kekayaan yang dimilikinya. Jadikan kekayaan itu sebagai kekuatan dan pemersatu bangsa.

\section{Disiplin}

Mustari (2011:42) menyatakan disiplin merujuk pada latihan yang membuat orang merelakan dirinya untuk melaksanakan tugas tertentu atau menjalankan pola perilaku tertentu, walaupun bawaannya adalah malas. Dengan demikian, disiplin adalah penundukan diri untuk mengatasi hasrat-hasrat yang mendasar. Nilai pendidikan karakter disiplin dapat dilihat pada gurindam yang berjudul “disiplin” berikut ini. 


\section{Disiplin}

Jadikanlah disiplin bagian diri Hendaklah mulai dari memahami

Jadikanlah disiplin sebagai budaya Niscayalah cepat maju suatu bangsa

Mengamalkan disiplin karena iman Itulah ibadah yang perlu ditegakkan

Menegakkan disiplin jangan menawar

Kelak harga diri menjadi hambar

Hendaklah disiplin bagian ajar Agar murid menjadi terpelajar

Dengan disiplin usaha menjadi mudah Kalau sudah niat menjadi ibadah

Untuk berdisiplin tidaklah susah Kalau niat di hati sudah terarah

Gurindam di atas menyampaikan bahwa manusia harus bersikap disiplin dalam kehidupan sehari-hari, baik itu disiplin dalam beribadah, maupun disiplin dalam melakukan hal lain. Jika disiplin menjadi budaya, maka suatu bangsa pasti akan maju, karena segala kegiatan akan selesai pada waktunya, tidak ada keterlambatan, sehingga segala hal akan berjalan lebih mudah dan baik. Disiplin tidak akan terasa susah jika sudah terbiasa. Apalagi jika niat hati sudah terarah, maka semua itu akan terhitung ibadah.

\section{Kerja keras}

Kerja keras adalah perilaku yang menunjukkan upaya secara sungguh-sungguh (berjuang hingga titik darah penghabisan) dalam menyelesaikan berbagai tugas, permasalahan, pekerjaan, dan lain-lain dengan sebaik-baiknya. Nilai pendikan karakter kerja keras dapat dilihat dalam gurindam yang berjudul Ikhtiar.

Ikhtiar

Barang siapa ingin mewujudkan niat

Tentulah syarat utama harus berbuat

Berbuatlah selalu dengan iman

Niscaya hasilnya akan membahagiakan

Ikhtiar disertailah dengan doa

Tandanya jiwa tak jumawa

Bilalah ikhtiar sudah mengkaji ilmu

Insya Allah rezeki sudah menuggu 


\section{Billalah ikhtiar tidak menyiapkan diri \\ Niscayalah kecewa diperoleh nanti \\ Barang siapa mengisi hidup penuh perjuangan \\ Niscayalah akan memetik kemenangan \\ Berjuang haruslah dengan percaya diri \\ Karenalah bumi dan langit untuk manusia sejati}

Isi dari gurindam ini adalah seorang manusia harus selalu beriktiar untuk mencapai suatu tujuan. Ikhtiar dapat diartikan usaha atau kerja keras seseorang untuk mencapai apa yang diinginkan. Bekerja keras dan berdoa dalam menjalani kehidupan menandakan bahwa sesorang bukan seorang yang angkuh. Dan hidup yang dilalui dengan perjuangan tentunya akan mencapai sebuah kemenangan.

\section{Kreatif}

Kreatif merupakan sikap dan perilaku yang mencerminkan inovasi dalam berbagai segi dalam memecahkan masalah, sehingga selalu menemukan cara-cara baru, bahkan hasil-hasil baru yang lebih baik dari sebelumnya. Nilai pendidikan karakter kreatif tercermin pada gurindam berikut ini.

Ide

Ide adalah makhluk pikiran

Berkembang luas dengan wawasan

Ide adalah makhluk berlian

Yang menangkap ayat-ayat Tuhan

Barang siapa mempunyai ide berlian

Samalah mempunyai sejuta kaki tangan

Ide adalah makhluk yang cerdas

Mengakir terus tuk mengenal kandas

Barang siapa tak punya ide sendiri Itulah pengikut yang tak mandiri

Ide cemerlang dapat mengubah dunia Begitulah kesempurnaan pikiran manusia

Isi dari gurindam di atas adalah sebagai makhluk yang cerdas manusia harus memiliki sikap kreaatif dalam menjalani kehidupan. Karena dengan sikap kreatif tujuan hidup akan lebih mudah dicapai, seperti pada kalimat ide selalu punya tujuan, layaknya anaak panah mengenal sasaran. Sikap kreatif akan muncul jika seseorang memiliki wawasan yang luas. Oleh karena itu, manusia 
tentunya harus banyak belajar dan mengikuti perkembangan dunia. dalam gurindam tersebut juga disebutkan bahwa sikap kreatif yang ada dalam diri manusia juga dapat mengubah dunia.

\section{Mandiri}

Mandiri adalah sikap dan perilaku yang tidak tergantung pada orang lain dalam menyelesaikan berbagai tugas maupun persoalan. Namun hal ini bukan berarti tidak boleh bekerjasama secara kolaboratif, melainkan tidak boleh melemparkan tugas dan tanggung jawab kepada orang lain. Nilai pendidikan karakter mandiri dapat dilihat pada gurindam berikut ini.

\section{Mandiri}

Barang siapa mampu mandiri Itulah dia percaya diri

Barang siapa selalu mandiri Itulah dia punya harga diri

Bilalah hidup senang mandiri Niscayalah mengenal kemampuan diri

Bilalah hidup mandiri rasa terhormat

Niscayalah jauh dari hidup melarat

Bilalah hidup mandiri penuh seni Itulah keindahan, kenikmatan yang dicari

Janganlah takut untuk mandiri

Takutlah menjadi dikasihani

Bilalah mengerti hakikat mandiri

Niscayalah hidup tak kurang rezeki

Mandiri adalah sebuah sifat yang tidak bergantung dengan orang lain. Nilai ini harus ditanamkan untuk menumbuhkan rasa mandiri dalam proses belajar maupun dalam kehidupan sehari-hari. Seperti yang terdapat dalam larik gurindam Bilalah hidup senang mandiri niscayalah mengenal kemampuan diri. Penanaman mandiri pada generasi muda ini perlu karena akan mengenal kemampuan dirinya sendiri. Hal ini dapat ditunjukan dengan memiliki rasa percaya diri dengan hasil atau karya sendiri dan tidak mencontek. Dalam proses pembelajaran, sudah seharusnya kita menanamkan nilai mandiri sebagai proses pembelajaran di kelas yang akan membentuk generasi terhormat dan terhindar dari hidup susah seperti dalam larik Bilalah hidup mandiri rasa terhormat Niscayalah jauh dari hidup melarat. Dengan gurindam tersebut mengajarkan kepada kita semua untuk tidak bergantung dengan orang lain. 


\section{Demokratis}

Demokratis adalah cara berpikir, bersikap dan bertindak yang menilai sama hak dan kewajiban dirinya dan orang lain (Mustari, 2011:167). Pendidikan karakter yang harus ditanamkan kepada generasi muda saat ini salah satunya adalah demokrasi. Nilai karakter dalam demokrasi perlu dipupuk agar generasi muda ditanamkan rasa menghargai, menghormati dan lebih bijaksana dalam menghadapi permasalahan yang ada di dunia ini. Kita sadar kita adalah bagian dari dunia ini. Dalam bertindak kita memperhatikan tanggung jawab, hak dan kebebasan yang dimiliki oleh setiap individu. Dengan domokrasi mendekatkan kita pada Tuhan, dengan penanaman moral yang terkandung dalam demokrasi tersebut. Demokrasi sangat penting dalam pendidikan saat ini karena tantangan ke depan semakin berat dan menuntut kita ikut berperan serta dalam perkembangan zaman. Generasi muda harus bisa mewujudkan cita-cita mulia dengan kebebasan yang dimilikinya untuk kepentingan orang banyak. Bila tidak maka akan berdampak pelaksanaan demokrasi tidak berjalan semestinya. Demokrasi kebebasan yang dimiliki yang memiliki batas-batas yang harus dipatuhi. Seperti dalam larik gurindam Bilalah dikatakan suara rakyat suara Tuhan Itulah hakikat demokrasi yang diharapkan.

Dengan pendidikan karakter demokrasi yang terdapat dalam gurindam ini dapat mengajarkan kepada generasi muda untuk menerima perbedaan tanpa adanya diskriminasi, mengahargai orang lain, rasa toleransi yang tinggi dan kebijaksanaan yang dimiliki sebagai cita-cita untuk menuju perdamaian yang diharapkan oleh masyarakat dan dunia. Hal ini dapat dilihat dari syair gurindam di bawah ini.

\footnotetext{
Demokratis

Bilalah dikatakan suara rakyat suara Tuhan Itulah angan yang masih di tangan

Bilalah dikatakan suara rakyat suara Tuhan

Itulah mimpi-mimpi yang harus diterjemahkan

Bilalah dikatakan suara rakyat suara Tuhan

Itulah hakikat demokrasi yang diharapkan

Demokrasi, suka-duka, rakyat semesta

Itulah yang perlu ditata dengan cinta

Bilalah demokrasi tanpa cinta

Akanlah memangsa induk semangnya

Bilalah demokrasi bukan suara Tuhan

Itulah wilayah kekuasaan setan

Bilalah demokrasi panggung sandiwara

Itulah hiburan sementara, sang sutradara
} 
9. Rasa ingin tahu

Berdasarkan isi gurindam terlihat nilai karakter yang dapat ditanamkan, yakni rasa ingin tahu. Karakter ini berasal dari olah pikir yakni salah satunya rasa ingin tahu yang berbentuk intelektual. Nilai ini terlihat dalam bait gurindam. Nilai yang ingin diterapkan adalah rasa ingin tahu. Nilai ini ingin diterapkan kepada peserta didik untuk menuntut ilmu dan selalu belajar untuk mencari tahu tentang dunia. Dengan ilmu yang dimiliki dapat meningkatkan pengetahuan dan pembentukan sikap yang tepat. Rasa ingin tahu haruslah ditanamkan dalam diri peserta didik agar mereka memiliki rasa ingin tahu yang tinggi. Seperti yang diketahui dalam asas pendidikan terdapat belajar sepanjang hayat. Dalam hal ini, kita tidak akan berhenti untuk belajar dan mencari ilmu sampai ke negeri Cina. Hal ini terlihat dalam larik Carilah ilmu sampai ke negeri Cina itulah petuah hadis harus dicerna. Hal serupa juga dijelaskan dalam larik gurindam Carilah ilmu olehmu sebanyak-banyaknya lebih bernilai dari tumpukan harta. Dengan begitu, dapat dikatakan bahwa rasa ingin tahu perlu ditanam dan dipupuk agar menciptkan generasi muda yang memiliki pengetahuan yang megakompetensi untuk menghadapi tuntutan zaman saat ini. Gurindam tersebut seperti di bawah ini.

Ilmu

Carilah ilmu sampai ke negeri Cina

Itulah petuah hadis harus dicerna

Carilah ilmu olehmu sebanyak-banyaknya

Lebih bernilai dari tumpukan harta

Ilmu dunia, ilmu akhirat

Karamah Allah untuk umat yang giat

Amalkan ilmu untuk maslahat

Niscaya hidup berlimpah rahmat

Bilalah ilmu dijadikan berhala

Rubuhlah iman di dunia

Gelar ilmu tandalah cendekiawan

Lebih indah kalau diamalkan

Gelar ilmu bukanlah sekadar pajangan

Itulah amanah untuk dipertanggungjawabkan

10. Semangat kebangsaan atau nasionalisme

Pendidikan karakter yang saat ini dibutuhkan untuk menghadapi era globalisasi adalah rasa nasionalisme. Dengan memiliki rasa nasionalisme kita mencintai negara kita sendiri dan berusaha menjaganya. Bila rasa nasionalisme tidak lagi dimiliki maka akan berdampak dengan keutuhan 
negara itu sendiri, seperti dalam larik gurindam Jika rasa nasionalisme sudah pudar Niscayalah kesatuan bangsa akan bubar. Bila rasa nasionalisme sudah pudar, budaya yang dianut tidak mencerminkan budaya Indonesia, rasa cinta dan bangga terhadap bangsa terkikis, akan berakibat kesatuan akan bubar. Oleh sebab itu, kesadaran kita untuk tetap mencintai dan bangga terhadap bangsa perlu dipupuk. Gurindam yang menunjukan nilai karakter nasionalisme seperti di bawah ini.

\author{
Nasionalisme \\ Barang siapa memahami nasionalisme dengan benar \\ Tidakklah dia tercabut dari akar \\ Barang siapa mengamalkan nasionalisme dengan cerdas \\ Pastilah sikap kebangsaannya jelas \\ Barang siapa menanam nasionalisme dengan sadar \\ Itulah pohon sejarah yang benar \\ Nasionalisme adalah ruh bangsa \\ Seharusnyalah jadi karakter yang terjaga \\ Bila rasa nasionalisme meluntur \\ Itulah tanda jiwa anak bangsa melantur \\ Jika rasa nasionalisme sudah pudar \\ Niscayalah kesatuan bangsa akan bubar \\ Nasionalisme adalah jantung kehidupan bangsa \\ Maka kesadaran bernegara denyut kehidupannya
}

11. Cinta tanah air

Nilai karakter rasa cinta tanah air atau nasionalisme juga terdapat dalam syair gurindam terhadap kecintaan NKRI. Hal ini dapat terlihat dari syair gurindam, yaitu Hendaklah NKRI sebagai kekuatan Agarlah tangguh menghadapi ancaman. Kesadaran yang kita tanamkan adalah penanaman terhadap nilai-nilai pancasila dalam meningkatkan rasa nasionalisme terhadap bangsa.

Hal ini dapat terlihat dari syair gurindam berikut.

\title{
NKRI
}

Hendaklah NKRI harga mati

Agarlah tak ada tawar menawar lagi

Hendaklah NKRI tekad bangsa

Mutlak dipelihara keutuhannya

Hendaklah NKRI sebagai kesadaran

Agarlah tidak ada keraguan

Hendaklah NKRI sebagai kekuatan

Agarlah tangguh menghadapi ancaman 


\author{
Bilamana NKRI goyah sudah \\ Niscayalah infiltrasi asing akan mudah \\ Agar NKRI berwibawa dan kuat \\ Hendaklah ideologi Pancasila sebagai perekat \\ Barang siapa tidak bangga dengan NKRI \\ Patutlah diragukan integritas diri
}

\title{
12. Komunikatif
}

Nilai karakter dalam komunikatif perlu dipupuk agar generasi muda mempunyai rasa menghargai, menghormati dan lebih bijaksana dalam menghadapi atau mendapat kritikan, tujuannya untuk meningkatkan pemahaman, memperluas apresiasi, atau membantu memperbaiki pekerjaan. Selain itu ketika berkomunikasi hendaklah tidak menyinggung perasaan seseorang gunakan bahasa yang santun. Hal ini terlihat dalam larik Pengkritik hendaklah santun Agarlah perbuatan terus tertuntun. Hal serupa juga dijelaskan dalam larik gurindam Pengkritik janganlah kecewa Penerima. Dengan demikian, kritikan yang diterima hendaknya diterima dengan tujuan untuk lebih baik lagi untuk kedepannya. Gurindam tersebut seperti di bawah ini.

\section{Kritik}

Memberi kritik hendaklah adil Agar tidaklah merasa kerdil

Kepada pengkritik janganlah marah Kalaulah memang bermasalah

Pengkritik hendaklah santun Agarlah perbuatan terus tertuntun

Apabila kritik tanpa dasar Itulah yang membuat gusar

Hendaklah mengkritik dengan cerdas Agar hasilnya berbalas jelas

Bilalah mengkritik untuk kebenaran Niscayalah didengar sebagai masukan Pengkritik janganlah kecewa Penerima

\section{Cinta damai}

Berdasarkan isi gurindam terlihat nilai karakter yang dapat ditanamkan, yakni sifat cinta damai. Dalam menjalani hidup, tentu pernah merasakan benci, sedih, kesal, kecewa, ataupun marah. Meminta maaf itu baik, tapi memaafkan jauh lebih baik seperti yang tertuang pada larik gurindam, yakni Allah saja Sang Maha Memaafkan Tidakkah kita bertauhid seiring sejalan?. Memaafkan 
merupakan akhlak mulia seperti dalam larik gurindam Suka memaafkan tentulah berhati mulia Niscayalah memahami tuntutan agama. Dengan memiliki sifat memaafkan, maka kita termasuk orang yang memiliki hati yang mulia dan mengajarkan kepada kita semua untuk saling memaafkan.

Memaafkan

Barang siapa tidak mau memaafkan yang salah

Tidakkah itu berlawanan dengan sifat Allah

Allah saja Sang Maha Memaafkan

Tidakkah kita bertauhid seiring sejalan?

Barang siapa terlebih dahulu memaafkan

Niscaya pahala besarlaaah sebagai ganjaran

Memaafkan hendaklah dari hati yang tulus Janganlah sampai dari akal bulus

Suka memaafkan tentulah berhati mulia Niscayalah memahami tuntutan agama

Memaafkan adalah ketegasaan iman

Tandalaah ikhsaan menuju kemuliaan

Maaf memaafkan perbutan terpuji

Itulah contoh yang diberikan nabi

14. Gemar membaca

Membaca merupakan kunci dalam proses belajar. Saat seseorang memiliki kemampuan membaca yang baik, maka ia akan dapat menyerap berbagai macam pengetahuan dan informasi. Seperti yang terdapat pada larik gurindam, yakni Bila kitab selalu dibuka Awaslah mata hati menyimaknya Bila kitab telah dibaca Niscaya ilmu menghuni kepala, Dengan membaca dapat menambah wawasan kita tentang apa yg kita belum ketahui selain itu kita juga dapat memperoleh pengetahuan. Dengan demikian mulai membiasakan diri dengan membaca buku-buku yang bermanfaat. Gurindam tersebut seperti di bawah ini.

\section{Membaca}

Bila kitab selalu di tangan

Tandalah insan senang bacaan

Bila kitab selalu dibuka

Awaslah mata hati menyimaknya

Bila kitab telah dibaca

Niscaya ilmu menghuni kepala

Bila otak sudah mencerna

Jadikanlah ilmu berdaya guna 
Bila bermacam kitab sudah dibaca

Terbukalah jalan menjadi alim ulama

Jadikanlah rumah sebagai pustaka

Niscaya penghuninya rajin membaca

Tidakkah pengarang buku berpayah-payah

Tinggal membacanya sangatlah mudah

\section{Peduli lingkungan}

Indonesia memiliki berbagai macam hutan lebat dengan pohon yang sudah berumur tua. Sebagai generasi muda kita perlu menjaga dan melestarikan hutan. Agar flora dan fauna yang berada di dalam hutan kehidupannya tidak terancam punah. Jangan biarkan hutan kita dirusak oleh tangan-tangan yang tidak bertanggungjawab yang tidak peduli dengan lingkungan dan kehidupan yang berlangsung yang ada di hutan, seperti flora dan fauna yang ada di hutan terancam punah akibat dari manusia yang serakah. Seperti yang terdapat pada larik gurindam Hutan Indonesia kaya raya Hendaklah terjaga habitat dan sumbernya. Dengan demikian, hutan salah satu jenis lingkungan hidup yang harus kita lestarikan keberadaannya.. Gurindam tersebut seperti di bawah ini.

\section{Hutan Rimba}

Hutan rimba Indonesia paru-paru dunia

Begitulah pengakuan adanya

Barang siapa merusaknya

Khianatlah dia akan bangsa negaranya

Barang siapa menebangnya

Hendaklah kembali menanamnya

Hutan rimba Indonesia raya

Itulah juga kerajaan flora dan fauna

Hutan Indonesia kaya raya

Hendaklah terjaga habitat dan sumbernya

Hutan rimba cagar alam semesta

Itulah karunia Allah untuk negara Indonesia

Barapang siapa tidak peduli kelestariannya

Itulah kufur nikmat mengundang bala

16. Peduli sosial

Rasa kebersamaan perlu ditanam dan terjalin agar menciptkan generasi muda yang memiliki sikap kebersamaan yang tinggi terutam dalam sosialnya. Gurindam tersebut seperti di bawah ini. 


\section{Kebersamaan}

Hendaklah kebersamaan menjadi budaya Agarlah kokoh kehidupan berbangsa

Berat dipikul, ringan dijinjing Itulah peribahasa untuk seiring

Kebersamaan sebagai warna budaya Janganlah sampai tinggal slogan saja

Sampah lingkungan di mana-mana Itulah luntur peduli rasa bersama

Korupsi semakin merajalela Itulah rasa kebersamaan manusia sirna

Kebersamaan ajaran agama Agar kasih sayang dalam hidup menjelma

Bilalah ajaran hanyaa didengar dan dibaca Niscayalah kebersaamaan hilang makna

\section{Tanggung jawab}

Mustari (2011:21) menyatakan tanggung jawab adalah sikap seseorang untuk melaksanakan tugas dan kewajibannya sebagaimana yang seharusnya dia lakukan, terhadap diri sendiri, masyarakat, lingkungan (alam, sosial, budaya), negara, dan Tuhan. Nilai pendidikan karakter tanggung jawab dapat dilihat dalam gurindam berikut ini.

\section{Guru}

Pekerjaan guru adalah mulia

Bila dilakoni dengan cinta

Jadi guru panggilan hati

Untuk anak bangsa di kemudian hari

Guru yang dikenang daan disenangi

Bila ajarnya telah memberi arti

Guru yang cerdas menjadi teladan

Karenalah dirinya agen perubahan

Jadilah guru garda budaya

Agar anak bangsaaa tidak terperdaya

Jadilah guru karena pengabdian

Supaya terhindar dari celaan

Nilai karakter yang telihat pada larik gurindam ini, yakni guru memiliki tanggung jawab sebagai pendidik professional dengan tugas utama mendidik, mengajar, membimbing, mengarahkan, melatih, menilai, dan mengevaluasi peserta didiknya. 


\section{SIMPULAN}

Sebuah karya sastra tidak hanya berfungsi sebagai hiburan, tetapi dapat dijadikan sebagai alat untuk membangun karakter. Sebuah karya sastra yang baik adalah karya sastra yang dapat mempengaruhi pembaca sehingga menjadi manusia yang lebih baik. Begitu pula dengan buku Banjar Negeri Harum 1001 Gurindam karya Haji Iberamsyah Barbary yang penuh dengan pesan kebaikan. Pendidikan Karakter dalam Buku Banjar Negeri Harum 1001 Gurindam Karya Haji Iberamsyah Barbary terdapat 18 karakter, yaitu: 1) religius, 2) jujur, 3) toleransi, 4) disiplin, 5) kerja keras, 6) kreatif, 7) mandiri, 8) demokratis, 9) rasa ingin tahu, 10) semangat kebangsaan atau nasionalisme, 11) cinta tanah air, 12) komunikatif, 13) cinta damai, 14) gemar membaca, 15) peduli lingkungan, 16) peduli sosial, 17) tanggung jawab.

\section{SARAN}

1. Dapat mempermudah dalam menangkap pendidikan karakter yang terkandung dalam buku 1001 Gurindam Karya Iberamsyah Barbary.

2. Dapat menjadi bahan pertimbangan ke depan untuk membuat yang karya berkualitas, khususnya yang memuat kearifan lokal.

3. Dapat memberikan informasi dan bahan referensi yang dapat digunakan oleh pemerhati keilmuan untuk melakukan penelitian yang lebih lanjut tentang gurindam.

\section{DAFTAR RUJUKAN}

Barbary, Iberamsyah. 2014. Banjar Negeri Harum 1001 Gurindam. Jakarta: Mexito.

Bogdan, Robert dan Steven J. Taylor. 1975. Pengantar Metode Penelitian Kualitatif. Terjemahan oleh Arief Furchan. 1992. Surabaya: Usaha Nasional.

Elisah, Tatik, Sofan Amri, dan Ahmad Jauhari. 2011. Implementasi Pendidikan Karakter dalam Pembelajaran. Jakarta: Prestasi Pustaka.

Gunawan, Heri. 2012. Pendidikan Karakter: Konsep dan Implementasi. Bandung: Alfabeta.

Mustari, Mohamad. 2011. Nilai Karakter: Refleksi untuk Pendidikan Karakter. Yogyakarta: LaksBang PRESSindo. 